\title{
THE EFFECTS OF MACROPRUDENTIAL POLICIES ON MANAGING CAPITAL FLOWS
}

\author{
Idil Uz Akdogan ${ }^{1}$
}

\begin{abstract}
The implementation of macroprudential policies for improving a country's financial stability have become more common in emerging markets. The aim of this paper is to analyse the effect of macroprudential policy on both capital flow volatility and price stability in emerging market economies. The analysis covers the Global Financial Crisis and post-crisis period. The effects of general macroprudential variables including leverage growth and credit growth and specific instruments, namely loan-to-value caps and reserve requirements on capital inflow, capital outflow and price stability have been tested. Propensity score matching techniques have been used to measure the effectiveness of various macroprudential policy measures on capital flow volatility.

Major findings indicate monetary policy instruments are effective in pursuing both monetary policy objectives and macroprudential objectives. Short term capital account volatility is seen to respond to macroprudential policy instruments. Propensity score matching was only successfully implemented for capital volatility. Results show that increased measures for macroprudential policy are effective for capital outflow and, decreased measures for macroprudential policy are effective, to a lesser extent, for capital inflows. Furthermore, meaningful correlation between increased macroprudential measures during periods of tight monetary policy exists only for capital outflows.
\end{abstract}

JEL: E58; F32; F34; G18

Key Words: Macroprudential Policy, Capital Flow, Global Financial Crisis.

\footnotetext{
${ }^{1}$ Department of Economics, Yeditepe University, Kayisdagi, 34755, Istanbul, Turkey. Tel: 00902165780722. Fax: 0090 2165780797. E-mail: idiluz@gmail.com
} 


\section{Introduction}

The recent global financial crisis called into question many of the convictions related to the implementation of central bank policies. Over the last decade, central banks have acquired more influence and assumed broader responsibilities. Macroeconomic policy objectives of price and output stability were traditionally achieved through conventional monetary policy tools such as short-term interest rates; the transparent central banking reaction function; changes in nominal interest rates (which subsequently lead to changes in yield curve of sovereign bonds and private asset classes, including bank loans); and the transmission mechanism through the credit channel, the exchange rate channel and the wealth channel (IMF 2013a). However, due to a dramatic change in the macroeconomic environment, conventional monetary policy tools were no longer perceived as being effective. Widespread financial disruptions, the increased vulnerability of some sectors and the recessionary environment that pushed nominal interest rates below the zero-lower bound, rendered conventional monetary policies and tools insufficient in the management and control of policy objectives. Consequently, the necessity for unconventional monetary policy arose. The IMF (2013b) outlined the objectives of unconventional monetary policy broadly as the restoring of financial markets, intermediation and providing further monetary policy accommodation at the zero lower bound. In this respect, macroprudential policy gathered more interest with the rise in the pursuit of unconventional monetary policy. The use of macroprudential policies was brought to the attention of policymakers for the first time in early studies from the mid-1980s. The focus of these early studies was on the safety and soundness of the financial system as a whole, as well as payment mechanisms (BIS 1986; Blunden 1987). Since then, capital flow, asset prices and credit growth have become important variables for the soundness of financial systems. Among these variables, cross-border capital flows attracted a substantial amount of concern from scholars, raising many policy challenges, particularly for emerging market economies.

This paper aims to measure the determinants of capital flow volatility in emerging economies for the duration of the Global Financial Crisis (GFC) and post-crisis period. The determinants of capital flow volatility have been analysed extensively in academic literature. Taylor and Sarno (1997) studied the determinants of large portfolio flows from the US to Latin American and Asian countries during 1988-92. They used cointegration techniques to analyse the effects of domestic and global factors on capital inflows and found them to have significant effect in the long run. In a recent study by Forbes and Warnock (2011), the major ebbs and 
flows of international capital, with a focus on extreme capital movements, was examined. Unlike other studies, little evidence in support of global factors such as US interest rate was discovered. The study did, however, put forward strong support for the role of the US interest rate in determining both capital inflows and outflows. Forbes and Warnock (2011) found productivity to be a key determinant of capital flows relevant in explaining gross capital inflow, but appeared to be less important for capital outflow for the post GFC period. This study found evidence that productivity was a significant determinant for capital outflows but not inflows for the post GFC period.

A more recent paper by Ahmed and Zlate (2013) examined only the determinants of new private capital inflow to emerging markets for 2002-2012 on a quarterly basis. Growth, interest rate differentials and risk aversion were found to be statistically significant. Significant changes in the behaviour of net inflows from the period before the GFC were detected when compared to the post crisis period, especially for portfolio inflows. These changes could be partly explained by a greater sensitivity to such flows as interest rate differentials and risk aversion. This study confirmed the role of interest rate differentials and risk aversion for both capital inflows and capital outflows

The use of the term 'macroprudential' became common after the financial crisis of 2007- $8^{2}$. Crockett (2001) put forward the idea of macroprudential conception of economic processes as being essential in understanding the nature of financial stability and hence being able to monitor and address it. His emphasis was more on macroprudential supervision and regulation rather than the microprudential approach in tackling financial stability. Galati and Moessner (2014) put forward opposing views on the use of capital controls as macroprudential policy instruments. FSB and BIS, for example, did not include capital controls as a macroprudential policy instrument because of its sole focus on foreign investors. The IMF, on the other hand, stressed the inclusion of capital controls as macroprudential instruments with the stipulation that they be geared towards systemic risk and supported by strict governance arrangements. This study confirmed the frequent use of capital controls by emerging markets, particularly during and post GFC, and included the effects of capital controls on the behaviour

\footnotetext{
${ }^{2}$ The use of macroprudential in published research databases was small due to lags in the publication process (see Galati 2011). Therefore, the large majority of the literature review and references in this area were from the working paper series.
} 
of both domestic and foreign investors. Surprisingly, the results showed that domestic investors, rather than foreign investors, were more responsive to tight capital controls. With the number of countries imposing new capital controls with the purpose of establishing financial stability rising, there was a risk, according to Gagnon (2011), that some might go further than justified by the circumstances and end up distorting capital in ways that were harmful rather than beneficial. Countercyclical capital buffers and provisions; capital requirements in different sectors; measures to contain liquidity and foreign exchange mismatches; loan-to-value caps (LTV's) and debt-to-income caps (DTI's); and constraints on the composition of assets and liabilities were the primary macroprudential tools commonly used in both emerging markets and advanced economies. Alternative policy instruments such as reserve requirements (monetary policy), levies imposed on wholesale funding (fiscal policy), derivative trading on exchanges (infrastructure policies) and takeover policies (competition policy) were also used to achieve macroprudential objectives. The IMF survey showed that two-thirds of the respondents had used various instruments for macroprudential objectives since 2008, with emerging market economies using these instruments more extensively than advanced economies both before and after the recent financial crisis (Lim et al. 2011). The reason for more extensive use of policy instruments by emerging economies was frequent exposure to shocks attributable to the risk of capital flight. Since the recent financial crisis, there have been an increasing number of countries using these instruments with greater frequency. Even though macroprudential policies were used both by advanced and emerging economies to maintain stability in the real economy, the perception of financial stability and soundness varies with the degree of economic and financial development of a country. A study by Akinci and Olmstead-Rumsey (2015) revealed that nearly all measures used in advanced economies targeted the housing sector rather than more general credit conditions. General credit conditions are generally targeted by emerging economies, consequently resulting in the more frequent and widespread use of macroprudential policy instruments or measures. These instruments, either directly or indirectly, affect the financial system and the real economy with an attempt to constrain both financial cycle and systemic risks (Kawata et al. 2013). Ostry et al. (2012) and IMF (2012) showed that macroprudential measures may improve a country's liability structure and its resilience to crises.

A number of policy constraints and measures are used in the pursuit of economic and financial stability. Forbes (2007), Cline (2010), Klein (2012) and IMF (2012) show limited effects of capital controls on capital flows and other macroeconomic variables. Due to the 
limited nature of knowledge, macroprudential policies could not be targeted perfectly and did not fully offset financial distortions (IMF 2013a). Imperfect institutions were cited as another constraint, as instruments, including credit related, liquidity-related and capital-related measures, varied across countries and were dependent on the degree of economic and financial development, exchange rate regime, and vulnerability to certain shocks (Lim et al. 2011). Varying regulations and financial structures may also have been a factor. The use of macroprudential policy in achieving domestic goals during the post-crisis period, was considered, to a certain degree, to be especially successful in developing countries. However, unconventional monetary policies had mixed effects in the rest of the world, especially when the major concern was about the effects of these instruments on large capital flows with increased risks of sudden reversals in Asia and Latin America (IMF 2013b).

The aim of this study is to measure the impact of macroprudential and monetary policy instruments on capital flow volatility and price stability in emerging market economies. It includes a panel data analysis for 25 emerging market economies. The effectiveness of macroprudential policy seems very much dependent on the interaction of other economic policies, mainly monetary policy. The empirical analysis of macroprudential instruments and their interaction between the financial system and macroeconomy was difficult to measure due to the lack of established models and availability of data (Galati and Moessner 2014). From a theoretical aspect, Unsal (2011) investigated whether macroprudential policy instruments assisted monetary policy in stabilizing the economy under a financial shock that was triggered by capital flow fluctuations. Angelini et al. (2012) studied the interaction between macroprudential policy and monetary policy in the European Union. Both Unsal (2011) and Angelini et al. (2012) examined the interaction between monetary and macroprudential policy by developing Dynamic Stochastic General Equilibrium (DSGE) models. Their simulations measured the effects of macroprudential and monetary models under supply and financial shocks.

The important contribution of this paper is to build a bridge between theoretical and empirical studies, by focusing on how macroprudential policy and monetary policy instruments are used in pursing central bank objectives, as well as empirically test the effectiveness of various instruments in pursuing different policy objectives. In addition to the analysis of the interaction between macroprudential and monetary policy, this paper also explores the behaviour of capital flows and the effectiveness of central bank policies on managing capital volatility. Capital flow management and central bank policies are essential; not only for policy 
makers but also for assuring that the economy is operating smoothly. They are essential for a sound financial system, for investors in making their decisions, and act as a backbone to prevent financial meltdowns in developing economies. The analysis includes the study of the behaviour of both domestic and foreign investors and how they respond to changes in monetary and macroprudential policy.

Bruno et al. (2015) concluded that successful macroprudential policies were introduced during periods of interest tightening. The results of our study also show evidence of increased measures for capital flows during periods of tight monetary policy. However, this relationship was meaningful for domestic investors, rather than foreign investors. Ostry et al. (2011) argued that there were costs associated with the use of capital controls, while evidence on the effectiveness of capital controls in influencing the volume of capital flows was mixed. Following the examination of the effects of capital controls on capital inflows, it was concluded that increased capital controls could create distortions, reducing good financial flows alongside bad ones. Our results showed that while increased controls influenced capital outflows, decreased controls affected capital inflows.

The effectiveness of macroprudential instruments on capital volatility was measured by using propensity score matching methodology. Propensity Score Matching (PSM) approach was developed in Rosenbaum and Rubin (1983) and has so far only been used in a small number of studies in the field of international macroeconomics. Glick, Guo, and Hutchinson (2006), for example, examined the effects of liberalised capital accounts and their link with the currency crisis. Recent studies show that there has been a growing interest in the use of PSM for measuring the effect of capital flow management. Forbes, Fratzscher, and Straub (2015) studied capital control and prudential measures, and Forbes and Klein (2013) analysed the policy responses to crisis and Bogdanov (2014) estimated the impact of open capital accounts on the volatility of international capital flows and foreign exchange rates.

Prior to this paper, it was common in academic literature to measure the effects of the implementation of instruments one at a time. This paper's major contribution has been the analysis of determinants of macroprudential policy with a focus on including several instruments for a specific county through a binary regression panel analysis. For example, the use of reserve ratios as a macroprudential policy instrument were more frequent in countries such as Brazil, Bulgaria, Bolivia, China, Latvia, Lithuania, Peru, Philippines, Poland, Romania, Russia and Kazakhstan. However, LTV ratios were more common for countries such as Chile, 
Korea, Hungary, India, Singapore, Thailand and credit standards on loans to households was more frequent in Albania. Furthermore, a single country was seen to have implemented different instruments at different periods of time. For example, India adjusted its cash reserve ratios extensively between 2008 and 2012 and changed LTV ratios in the last quarter of 2010. Thus, the use of binary analysis in this paper allowed to consider country-specific and timespecific factors simultaneously in single regression analysis, which in turn eliminated the time inconsistency problem.

The study is structured as follows: Section 2 explains the theoretical framework and the model. Section 3 explains propensity score matching, while section 4 presents the estimation results. The conclusions of the study are drawn in section 5 .

\section{The Theoretical Framework and Model}

In literature, factors that affected capital movements in emerging markets were separated under two groups: country-specific - pull - factors and global - push - factors (Taylor and Sarno 1997). The first group reflected domestic opportunity and risk and the latter reflected global factors such as changes in the US monetary policy and/or other macroeconomic policies and institutional reforms in emerging markets.

An analytical framework for capital flow volatility was developed by Fernández-Arias and Montiel (1996) and Taylor and Sarno (1997). Potential domestic causes were broken down into causes operating at the project level and at the country level. It was assumed that capital flows might be transactions in $n$ different types of assets, indexed by $s(s=1, \ldots, n)$. The first is a project-level return on an asset $\left(G_{s}\right)$ and the other is an adjustment factor depending on the creditworthiness of the country $\left(C_{s}\right) . G_{s}$ is a function of a vector of net flows $(F)$ and $C_{s}$ is a function of a vector of the end-of-period stocks of liabilities of all types, $S: S=S_{-1}+F$, where $S$. I denotes initial stocks of liabilities. Fernández-Arias and Montiel (1996) and Taylor and Sarno (1997) established the following arbitrage condition:

$$
G_{s}(g, F) C_{s}\left(c, S_{-1}+F\right)=V_{s}\left(v, S_{-1}+F\right)
$$

where $V_{s}$ was the opportunity cost of assets of type $s$, and $g, c$, and $v$ represented shift factors associated with the domestic economic environments, domestic creditworthiness and the 
financial conditions of the creditor country. $G_{s}, C_{s}$ and $V_{s}$ were the increasing functions of $g, c$ and $v$. The equilibrium value of the vector of net flows, $F$, was determined explicitly from the above equation and given as:

$$
F=F\left(g, c, v, S_{-1}\right)
$$

where $F$ was positively related with $g$ and $c$, and negatively related with $v$ and $S_{-1}$. According to Taylor and Sarno (1997), when equation 2 was differentiated and total derivatives approximated by their first differences, holding $S_{-1}$ as constant, the equation took the following form:

$$
\Delta F=F_{1} \Delta g+F_{2} \Delta c+F_{3} \Delta v
$$

where subscripts denoted partial derivatives. This form of the equation was used to describe the changes in capital flows due to changes in the pull factors $g$ and $c$ and the push factors $v$ with the initial value of S. The Generalised Method of Moments (GMM) (Hansen, 1982) was used to test the domestic pull and global push factors.

Due to the non-stationary nature of some of the series used for analysis in this study, the Arellano and Bond (1991) difference GMM estimator technique has been used. Arellano and Bond (1991) proposed a method that exploits all possible instruments. Using the GMM, they obtained estimators using the moment conditions generated by lagged levels of the

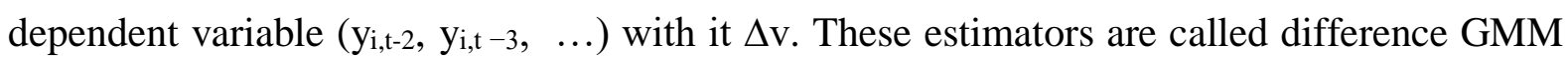
estimators. The model is as follows:

$\Delta K A_{i t}=\beta_{0}+\beta_{1} \Delta K A_{i t-1}+\beta_{2} \Delta i_{i t}+\beta_{3}\left(i-i^{u s}\right)_{i t}+\beta_{4} \Delta V I X_{i t}+\beta_{5} \Delta L_{i t}+\beta_{6} \Delta C R_{i t}+\beta_{7} \Delta G_{i t}+\beta_{8} M P I_{i t}+\varepsilon_{i t}$

$\Delta I N F_{i t}=\beta_{0}+\beta_{1} \Delta I N F_{i t-1}+\beta_{2} \Delta i_{i t}+\beta_{3}\left(i-i^{u s}\right)_{i t}+\beta_{4} \Delta V I X_{i t}+\beta_{5} \Delta L_{i t}+\beta_{6} \Delta C R_{i t}+\beta_{7} \Delta G_{i t}+\beta_{8} M P I_{i t}+\epsilon_{i t}$

where $K A$ is the share of capital account (portfolio investment assets) in GDP. It is either $K A I$, the gross capital inflow (foreigners' portfolio investment, liability) or $K A O$, the gross capital outflow (residents' portfolio investment, asset). Buying security is a plus sign and selling security is a negative sign both for capital inflow and outflow. The subscript $i$ denotes the $i$ 'th 
country, the subscript $t$ denotes the $t^{\prime}$ th quarter and, $\varepsilon_{i t}$ is the error term. INF is the inflation rate, $i$ is the monetary policy related interest rate. $i-i^{u s}$ is the interest rate differential between domestic and the US nominal interest rates to capture short-term return differentials. It affects the relative attractiveness of domestic versus foreign assets, and thus capital flows. For example, when there is reduction in the interest rate in advanced economies, investors try to rebalance their portfolios toward higher-yielding assets, resulting in capital inflows to emerging markets (Powell, 2013). VIX is the Chicago Board Options Exchange Rate Market Volatility Index used as a proxy for risk aversion and uncertainty. $L$ is the banking sector leverage ratio that is common in literature because of its role in causing financial instability, especially after the Spanish and Irish banking crisis. In today's environment of excessive liquidity, bank leverage ratios are viewed as key part of macroprudential framework (Augouleas 2015). It is equal to the ratio of claims in private sector to transferable and other deposits in Broad Money of Depository Corporations excluding central banks. $C R$ is the domestic credit growth rate ${ }^{3}$. It is a useful measure for indicating the stage of the financial sector. Macroprudential variables such as leverage and credit growth are not tools but rather measures that can reinforce prudential regulations (see Oustry et al. 2010). $G$ is the economic growth rate that is used as proxy for the state of a country's business cycle. Fast growing economies are more likely to increase their capital inflow not only because of the potential needs for financing their investment, but also because investors (especially for equity flows) may be attracted to the potential productivity gains and corresponding returns. Therefore, real GDP growth rate is included in the model. MPI is a macroprudential policy instrument. There are two instruments: $L T V$, caps on loan-to-value ratios (aimed at borrowers), that restricts the amount of the loan so as not to exceed some percentage of the value of the collateral asset (see Shin, 2014) and $R R$, reserve requirement (aimed at institutions) $)^{4}$.

There are several econometric problems that may arise from estimating these equations. The first one is that credit growth and leverage growth variables are assumed to be endogenous and causality may run in both directions - from capital flow volatility to credit growth volatility and vice versa - these regressors may be correlated with the error term. The second one is that time-invariant country characteristics may be correlated with the explanatory variables. The fixed effects are contained in the error term that consists of the unobserved country-specific

\footnotetext{
${ }^{3}$ It mirrors the risk-taking attitudes or market risk premiums.

${ }^{4}$ See appendix 7.1 for a detailed explanation of the variables used in the estimation equations.
} 
effects and the observation specific errors. The last problem is that the panel has a short time dimension $(T=21)$ and a larger country dimension $(N=25)$.

The Arellano - Bond (1991) difference GMM estimator was used to address and solve the above problems. This requires the use of first-differences of all variables in the model and their lagged levels as instruments ${ }^{5}$. By transforming the regressors by first differencing, the fixed country-specific effect is removed. Arellano - Bond (1991) is also better for small $T$ larger $N$ (see Rodman 2006). The results of the estimations are explained in Section 4.

\section{Propensity Score Matching}

An important part of this study is to measure the effectiveness of macroprudential policy implications on capital flow management using the Propensity Score Matching (PSM) technique (Rosenbaum and Rubin 1983). Matching to improve causal inferences in observation data is a highly popular method for pre-processing data (Ho et al. 2007; Morgan and Winship 2015). The question that this paper tries to find an answer to is what fraction of capital volatility has been prevented by the central banks' macroprudential policy. This is a causal question because it requires some knowledge of the data generating process; it cannot be computed from the data alone, regardless of sample size. PSM is the most commonly used matching method for causal analysis in observational studies (Pearl 2010). It applies to all situations where there is treatment, a group of treated individuals and a group of untreated individuals. The nature of treatment may take various forms. In this study, the changes in macroprudential policy are considered treatment. The observations that receive treatment are considered participants, the observations that do not receive treatment are considered nonparticipants, and the outcome is the capital flow volatility.

The focus is on pointing out the difference between participants' outcomes, both with and without treatment. In other words, we want to see the effect of macroprudential policy on countries' capital volatility with and without treatment. The problem arises with the desire to observe both outcomes (with and without policy changes) for the same country at the same time. Mean outcome of nonparticipant may not be appropriate since participants and nonparticipants usually differ in the absence of treatment. This problem is called as selection

\footnotetext{
${ }^{5}$ Unit root test results show that all variables other than VIX and banking sector leverage ratio are found stationary.
} 
bias and the matching approach is one possible solution to the selection problem. PSM is based on the idea that we try to find observations in a large group of nonparticipants that are similar to the participants in all relevant predetermined characteristics of $\mathrm{X}$, called covariates. Rosenbaum and Rubin (1983) use so called balancing scores $b(\mathrm{X})$, which are the functions of the relevant observed covariates $\mathrm{X}$ such that the conditional distribution of $\mathrm{X}$ given $b(\mathrm{X})$ is independent of assignment into treatment. This is called propensity score, the probability of participating in a policy given observed characteristics X. Matching procedures based on this balancing score are known as propensity score.

Basic steps for implementing PSM are defined by Sianesi (2001) to be as follows:

1. Estimate propensity scores on the covariates using probit or logit and retrieve their predicted values ${ }^{6}$.

2. Pair each participant with some group of comparable nonparticipant (on the bases of propensity score) by using different algorithms.

3. Estimate the counterfactual outcome of participant as weighted outcomes of her neighbours in the comparison group.

After the estimation of propensity scores of the covariates, the next step is to match participants with the same propensity scores. There are various types of matching algorithms used to pair nonparticipants with participants. One method is the nearest neighbour (NN) matching method used in this study. The individual from the comparison group is chosen as a matching partner for a treated individual that is closest in terms of propensity score. There are two possible ways to conduct NN matching: one way is 'with replacement', the other is 'without replacement'. In the former case, an untreated individual can be used more than once as a match, whereas in the latter case it is considered only once.

Another algorithm used in this study is the five nearest neighbour matching $(5 \mathrm{NN})$. In this algorithm, the individuals from the comparison group are chosen as a matching partner for a treated individual that is five closest in terms of propensity score.

The last algorithm is Kernel matching (KM), a non-parametric matching estimator that uses the weighted averages of all individuals in the control group to construct the

\footnotetext{
${ }^{6}$ This study followed Forbes et al. (2015) and used logit instead of probit model in order to "spread out" the density of scores at very low and high propensity scores. There are seven covariates used.
} 
counterfactual outcome. Common support condition is an important factor that determines the quality of the matching. It is more important for the implementation of $\mathrm{KM}$ than it is for the implementation of NN-matching. In the latter, all untreated observations are used to estimate the missing counterfactual outcome whereas in NN-matching, only the closest neighbour (in $5 \mathrm{NN}$-matching the five closest neighbours) is used (Caliendo and Kopeinig 2005). One major advantage of this approach is the lower variance achieved which can be attributed to the use of more information. A drawback of these methods is that possibly observations are used which may be poor matches.

\section{Estimation Results}

The focus of this analysis is to firstly attempt to measure the effects of some macroprudential variables on net capital flows and inflation in emerging market economies. Then, the study focuses on measuring the effect of changes in macroprudential policy measures on capital flows using propensity score matching methodology.

Table 1. Determinants of Capital Inflows

\begin{tabular}{|c|c|c|c|c|c|c|}
\hline \multicolumn{7}{|c|}{ DEPENDENT VARIABLE: CAPITAL INFLOWS (KAI) } \\
\hline C & 0.0073 & $* * *$ & 0.0910 & $* * *$ & 0.0504 & $* * *$ \\
\hline $\operatorname{KAI}(-1)$ & -0.2570 & $* * *$ & -0.2536 & $* * *$ & -0.2545 & $* * *$ \\
\hline $\mathrm{i}$ & 0.0536 & $* * *$ & 0.0510 & $* *$ & 0.0403 & $*$ \\
\hline$i-i^{\text {us }}$ & -0.0597 & $* * *$ & -0.0677 & $* * *$ & -0.0588 & $* * *$ \\
\hline VIX & -0.0002 & $* * *$ & -0.0001 & $* *$ & -0.0001 & $* * *$ \\
\hline LEVG & -0.0000 & & 0.0000 & & -0.0000 & \\
\hline CR & 0.0001 & $* *$ & 0.0002 & $* * *$ & 0.0002 & $* * *$ \\
\hline G & 0.0000 & & 0.0001 & & -0.0002 & \\
\hline LTV & & & -0.1508 & $* * *$ & & \\
\hline $\mathrm{RR}$ & & & & & -0.0680 & $* * *$ \\
\hline Instrument rank & 21 & & 21 & & 21 & \\
\hline Sargan Test & 0.18 & & 0.38 & & 0.30 & \\
\hline
\end{tabular}

Data includes 25 emerging economies and the dataset covers the period 2008-2013 on a quarterly basis. Table 1 shows the estimation results for measuring the effects of monetary and macroprudential instruments on capital flow of foreign investors. Official interest rates and 
interest rate differentials were used to measure the effects of policy responses in capital flow volatility and found them to be statistically significant. Their signs are consistent with the literature, in that, as the neoclassical theory predicts, the capital should respond to interest rate differentials between countries. There is capital flow from countries with low return (capitalscarce EMEs). The positive sign of the interest rate means that it is more attractive for foreign financial investors to invest at high interest rate. Subsequently, as the federal funds rate increases, foreign investors leave emerging markets.

It is common in literature to measure the effect of asset price volatility on capital flows. The coefficient of VIX, which represents risk aversion and uncertainty (Miranda-Agrippino and Rey 2012; Rey 2013), is statistically significant and it has a negative correlation to capital flow and VIX. Low VIX requires high carry trade and high VIX requires low carry trade. Low VIX means low uncertainty and risk aversion which in turn increases capital inflows. Nier et al. (2014) found the effect of VIX on capital flow to be significant. Over the past number of years, there has been growing concern that leverage - or risk taking in general - has been shifting from banks to non-banks both in mature and emerging economies ${ }^{7}$ (IIF 2015). The results of this study show that the banking leverage growth rate is not found to be statistically significant. Credit growth rate, on the other hand, is statistically significant yet the magnitude is relatively small. It shows that it is the non-banking sector borrowing rather than the financial sector borrowing that determines capital inflow fluctuations for emerging economies. The possible causes of this decline in banking sector leverage can be explained by regulatory changes, market pressure and changes in bank business strategies.

The estimation results show that the domestic business cycle fluctuation is not statistically significant. In other words, domestic production fails to explain capital flow volatility. This result contradicts standard economic theory predicting that capital should flow into countries with an increase in total factor productivity. However, over the last decade, evidence shows the opposite. Studies such as Prasad et al. (2007) and Gourinchas and Jeanna (2006) show capital outflows from countries with fast growing productivity. This study finds evidence that foreign investors are not concerned with domestic production growth rates. Carry

\footnotetext{
7 The share of bond market funding in the US was more than 50\% in 2007 and it was increased to $70 \%$ in 2014. This was $14 \%$ in euro area in 2007 and increase $\mathrm{d}$ to $21 \%$ in 2014 . We see similar trends in emerging markets. For example, in Latin America, it increased from 27\% in 2007 to $42 \%$ in 2014; in Asian markets, it increased from $25 \%$ in 2007 to $35 \%$ in 2014 . Nevertheless, the share of non-financial corporate indebtedness to GDP in 2000 was around $89 \%$ in mature markets and 53\% in emerging markets. In 2014, this increased to $95 \%$ in mature markets and more than $80 \%$ in emerging markets (see IFF 2015, p.3)
} 
trade is still important and this increases vulnerabilities in emerging markets. Finally, the GMM estimation used two dummies; loan-to-value (LTV) ratio and reserve requirements (RR). The observation took the value 1 when there was a change in these instruments and 0 otherwise. Both the LTV ratio and reserve requirement coefficients are statistically significant. Higher limitations lower capital inflow movement.

Table 2. Determinants of Capital Outflows

\begin{tabular}{|c|c|c|c|c|c|c|}
\hline \multicolumn{7}{|c|}{ DEPENDENT VARIABLE: CAPITAL OUTFLOWS (KAO) } \\
\hline C & 0.0109 & $* * *$ & -0.1346 & $* * *$ & -0.0492 & \\
\hline $\mathrm{KAO}(-1)$ & -0.4800 & $* * *$ & -0.4832 & $* * *$ & -0.5229 & $* * *$ \\
\hline $\mathrm{i}$ & 0.0432 & $* * *$ & 0.1082 & $* *$ & 0.0970 & $* * *$ \\
\hline $\mathrm{i}-\mathrm{i}^{\mathrm{us}}$ & -0.0327 & $* * *$ & -0.0752 & $* *$ & -0.0648 & $* * *$ \\
\hline VIX & -0.0002 & $* * *$ & -0.0003 & $* * *$ & -0.0003 & $* * *$ \\
\hline LEVG & -0.0000 & & -0.0001 & $* * *$ & -0.0000 & \\
\hline CR & 0.0000 & & -0.0002 & $* * *$ & -0.0000 & \\
\hline G & 0.0002 & $* * *$ & 0.0002 & $* *$ & 0.0007 & $* * *$ \\
\hline LTV & & & 0.2687 & $* * *$ & & \\
\hline $\mathrm{RR}$ & & & & & 0.1021 & $* *$ \\
\hline Instrument rank & 21 & & 21 & & 21 & \\
\hline Sargan Test & 0.15 & & 0.38 & & 0.30 & \\
\hline
\end{tabular}

Table 2 shows the estimation results for capital flow of domestic investors. Both the official interest rate and the interest rate differential are statistically significant. A positive sign for the official interest rate means that if central banks raise interest rates there will be an increase in capital outflow for emerging economies. This means that domestic investors sell securities. Banking leverage rate and credit growth rate are statistically significant only in one of three estimates. The effect is relatively small. They both have negative signs. As the rates increase, domestic investors in emerging markets buy securities in foreign markets. Domestic business cycle fluctuations are statistically significant for domestic portfolio investors. A positive sign means that when the economic growth rate increases, domestic investors sell foreign securities. Finally, macroprudential instruments are statistically significant and have positive signs. When the limits for domestic borrowing are increased, domestic investors buy foreign securities.

In table 3, official interest rates and interest rate differentials are both statistically significant. The domestic interest rate has the greatest value for determining price stability, 
which is consistent with theory and literature. VIX, representing uncertainty and risk, is statistically significant but relatively small in magnitude. It has a positive sign, meaning that high uncertainty results higher inflation rates in emerging market economies. A negative correlation between inflation and the variables such as rate of credit growth, leverage growth and output growth shows that reduction in credit growth (borrowing) changes expectations and causes an increase in inflation (Bose 2002). Finally, macroprudential policy instruments are not a statistically significant variable for the inflation rate.

Table 3. Determinants of Inflation

\begin{tabular}{|c|c|c|c|c|c|c|}
\hline \multicolumn{7}{|c|}{ DEPENDENT VARIABLE: INFLATION } \\
\hline C & -0.0668 & & -0.6961 & & -0.2350 & \\
\hline $\operatorname{INF}(-1)$ & 0.2984 & $* * *$ & 0.3204 & $* * *$ & 0.2960 & $* * *$ \\
\hline $\mathrm{i}$ & 1.1567 & $* * *$ & 1.3937 & $* * *$ & 1.3552 & $* * *$ \\
\hline i-jus & -0.7719 & $* * *$ & -0.8863 & $* * *$ & -0.8562 & $* * *$ \\
\hline VIX & 0.0016 & $* * *$ & 0.0008 & & 0.0013 & $*$ \\
\hline LEVG & -0.0011 & $*$ & -0.0014 & $*$ & -0.0013 & $* *$ \\
\hline CR & -0.0027 & $* * *$ & -0.0034 & & -0.0029 & $* * *$ \\
\hline G & -0.0035 & & -0.0037 & & -0.0022 & \\
\hline LTV & & & 1.2413 & & & \\
\hline RR & & & & & 0.3061 & \\
\hline Instrument rank & 21 & & 21 & & 21 & \\
\hline Sargan Test & 0.28 & & 0.29 & & 0.21 & \\
\hline
\end{tabular}

$*, * *, * * *$ indicate statistical significance at $10 \%, 5 \%$ and $1 \%$ test levels, respectively. See section 6.1 Data for abbreviations.

The second part of the analysis aims to measure the effectiveness of any changes in macroprudential policy measures in managing capital flow volatility by using propensity score matching methodology. Table 4 shows the estimation output for binary regressions. It includes all the variables in equation 4, except this regression includes the growth of VIX and excludes dummy variables of LTV and RR as macroprudential policy instruments ${ }^{8}$. In addition, inflation rate and exchange rate growth have been introduced and credit growth rate has been excluded from the model to improve robustness. Three binary regressions are estimated; macroprudential policy includes any change in policy - both increasing and decreasing measures. Contractionary estimation includes only increased measures and expansionary estimation includes policy changes causing decreased measures. All macroprudential and monetary variables are

\footnotetext{
${ }^{8} \mathrm{LTV}, \mathrm{RR}$ and other instruments are used to represent endogenous variables in binary regression.
} 
statistically significant, especially for macroprudential policy estimate, and the signs of the coefficients are consistent with literature.

Table 4. Estimation output for binary regression

\begin{tabular}{cccc}
\hline \multicolumn{4}{c}{ FIRST-STAGE LOGIT REGRESSION RESULTS USED TO CALCULATE PROPENSITY SCORES } \\
MACROPRUDENTIAL POLICY & CONTRACTIONARY & EXPANSIONARY \\
\hline \hline $\mathrm{i}$ & $-1.604^{* * *}$ & -0.982 & -1.345 \\
$\mathrm{i}-\mathrm{i}$ us & $1.537^{* * *}$ & 0.679 & $1.523 *$ \\
VIX & -0.003 & 0.023 & $-0.067 * *$ \\
LEV & $7.873^{* * *}$ & $9.096 * *$ & 0.008 \\
G & $0.024^{* *}$ & $0.027 *$ & -0.016 \\
INF & $-0.015^{* *}$ & 0.074 & -0.016 \\
EXR & $-0.030 * *$ & -0.015 & -0.020 \\
Observations & 545 & 545 & 545 \\
Pseudo R & 0.120 & 0.090 & 0.197 \\
\hline$*, * *, * * *$ indicate statistical significance at 10\%, $5 \%$ and $1 \%$ test levels, respectively. \\
Note: Equations include constant and lagged variables of the control variables.
\end{tabular}

There is a negative correlation between interest rates and macroprudential policy measures. When domestic interest rates are high, emerging market economies are reluctant to intervene in capital markets and find it unnecessary to use any macroprudential policy measures. However, regression did not provide a statistically significant result when macroprudential policy was broken down into contractionary and expansionary dimensions. There is a positive correlation between interest rate differential and policy change. This means that when the US interest rate falls, emerging economies more likely reduce measures to attract foreign investment. VIX has similar behaviour with the GMM estimate. The negative sign implies that when there is uncertainty in the global markets, emerging economies reduce their macroprudential measures. Unlike in the GMM estimation, the effect of leverage growth rate on macroprudential policy is statistically significant and high in magnitude in the binary estimation. It shows that central banks respond to the level of risks in financial sectors. At higher growth rates central banks are more likely to intervene in capital flow management thereby using macroprudential policy instruments more frequently. The relationship between inflation and policy implication is similar with the results for the behaviour of inflation in GMM estimation. When inflation rises, these economies reduce their measures. A final variable is exchange rate growth, where depreciation causes reduction in the use of macroprudential policy instruments.

The binary regression results are used to calculate propensity scores. The choice of covariates is based either on theory or on previous empirical findings. The next stage is to apply 
propensity score matching by using different algorithms. The aim is to match treated capital flows with similar untreated capital flows in order to evaluate the impact of macroprudential policy on different outcomes such as capital inflows and outflows. To make sure that these findings are not driven by the selection of a particular strategy, coefficients are estimated using different matching algorithms. These algorithms are: nearest neighbour matching, five nearest neighbour matching and Gaussian Kernel matching. Tables 5, 6 and 7 report the calculation of the average treatment effect on the treated for three different policy implications. Table 5 shows the use of macroprudential measures (both increased and decreased measures) in a single binary regression. Table 6 shows increased measures only and table 7 shows decreased measures for capital volatility. After the propensity scores are estimated, standard errors are bootstrapped for the ATT in order to evaluate if there is a significant difference between the treated and control groups (see Lechner 2002).

The first two columns are the means of treated and control groups for each of the variables prior to matching. The third column shows the covariance balance, which is a criterion for standardised difference showing whether matching is necessary. The matching technique is meaningful for covariates if means of treated and untreated control variables are statistically different. A value higher than 20 indicates the necessity to balance out variables. The results of table 5 show that when the analysis covers expansionary and contractionary macroprudential policy mean of the treated and unmatched control is significantly different for variables other than leverage growth rate, domestic growth rate and exchange rates. So, matching is needed for variables such as central bank interest rate, interest rate differential, VIX and inflation rate. However, when the analysis is divided into either increased or decreased macroprudential measures, means of treated and unmatched control are statistically different for nearly all variables that allow us to use matching technique. The other columns show the mean matched values for ATT both for capital inflow (KAI) and capital outflow (KAO) by using three different matching algorithms and the $t$-statistics for tests of the hypothesis that the mean of each variable in the treated and control groups are equal. This means that all the covariates are well balanced and matching was effective in building a good control group. The NN matching for increased macroprudential measures on capital outflow successfully removed the significant differences across groups as measured by the seven covariates. The $5 \mathrm{NN}$ matching for increased macroprudential measures on capital outflow successfully removed the significant differences across groups as measured by the six covariates, on capital inflow only by five covariates. Alternatively, NN matching for increased measures on capital inflow 
successfully removed the significant difference across groups as measured by covariates, except interest rates and growth rates. Results for the growth rates are statistically insignificant and consistent with results of the GMM.

Table 5. Average Treatment Effect for Macroprudential Policy Measures

MACROPRUDENTIAL POLICY MEASURES ON CAPITAL FLOWS:

MEANS FOR TREATED AND CONTROL GROUPS USING DIFFERENT MATCHING ALGORITHMS

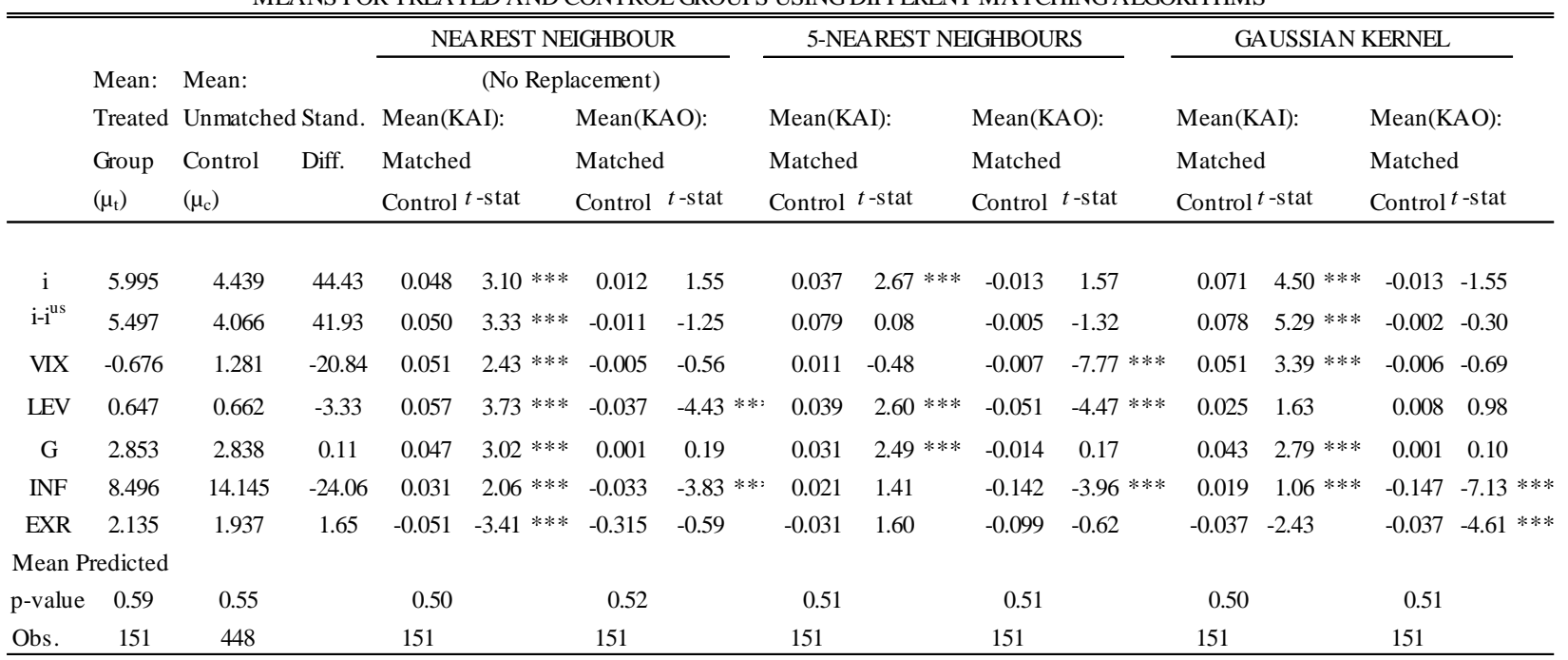

$*, * *, * * *$ indicate statistical significance at $10 \%, 5 \%$ and $1 \%$ test levels, respectively (Bootstrap with 1000 repetitions)

Note: Equations include constant and lagged variables of the control variables.

Table 6. Average Treatment Effect for Increased Macroprudential Measures

INCREASED (CONTRACTIONARY POLICY) MEASURES ON CAPITAL FLOWS: MEANS FOR TREATED AND CONTROL GROUPS USING DIFFERENT MATCHING ALGORITHMS

\begin{tabular}{|c|c|c|c|c|c|c|c|c|c|c|c|c|c|c|c|}
\hline & \multirow{3}{*}{$\begin{array}{l}\text { Mean: } \\
\text { Treated } \\
\text { Group } \\
\left(\mu_{\mathrm{t}}\right)\end{array}$} & \multirow[b]{2}{*}{ Mean: } & & \multicolumn{4}{|c|}{ NEAREST NEIGHBOUR } & \multicolumn{4}{|c|}{ 5-NEAREST NEIGHBOURS } & \multicolumn{4}{|c|}{ GAUSSIAN KERNEL } \\
\hline & & & & \multicolumn{4}{|c|}{ (No Replacement) } & & & & \\
\hline & & $\begin{array}{l}\text { Unmatchec } \\
\text { Control } \\
\left(\mu_{c}\right)\end{array}$ & $\begin{array}{l}\text { Stand. } \\
\text { Diff. }\end{array}$ & \multicolumn{2}{|c|}{$\begin{array}{l}\text { Mean(KAI): } \\
\text { Matched } \\
\text { Control } t \text {-stat }\end{array}$} & \multicolumn{2}{|c|}{$\begin{array}{l}\text { Mean(KAO): } \\
\text { Matched } \\
\text { Control } t \text {-stat }\end{array}$} & \multicolumn{2}{|c|}{$\begin{array}{l}\text { Mean(KAI): } \\
\text { Matched } \\
\text { Control } t \text {-stat }\end{array}$} & \multicolumn{2}{|c|}{$\begin{array}{l}\text { Mean(KAO): } \\
\text { Matched } \\
\text { Control } t \text {-stat }\end{array}$} & \multicolumn{2}{|c|}{$\begin{array}{l}\text { Mean(KAI): } \\
\text { Matched } \\
\text { Control } t \text {-stat }\end{array}$} & \multicolumn{2}{|c|}{$\begin{array}{l}\text { Mean(KAO): } \\
\text { Matched } \\
\text { Control } t \text {-stat }\end{array}$} \\
\hline $\mathrm{i}$ & 5.61 & 4.70 & 36.25 & 0.091 & $3.894 * * *$ & 0.001 & 0.08 & 0.057 & $2.51 * *$ & 0.002 & 0.13 & 0.089 & $3.65 * * *$ & 0.002 & 0.12 \\
\hline $\mathrm{i}-\mathrm{i}^{\mathrm{us}}$ & 5.07 & 4.32 & 63.21 & 0.037 & 1.612 & 0.020 & 1.57 & 0.020 & 0.87 & 0.080 & $6.55 * * *$ & 0.028 & 1.20 & 0.070 & $5.76 * * *$ \\
\hline VIX & 0.99 & 0.72 & 5.09 & 0.031 & 1.304 & 0.010 & 0.65 & 0.018 & 0.79 & 0.000 & 0.01 & 0.070 & $2.89 * * *$ & 0.008 & 0.68 \\
\hline LEV & 0.64 & 0.66 & -25.29 & 0.076 & $3.232 * * *$ & 0.012 & -1.76 & 0.064 & $2.76 * * *$ & -0.037 & -1.84 & 0.024 & 1.06 & -0.453 & $2.17 * *$ \\
\hline G & 3.91 & 2.67 & -42.25 & 0.065 & $2.840 * * *$ & $=0.016$ & 1.23 & 0.047 & 1.99 & 0.008 & 0.67 & 0.062 & $2.61 * *$ & 0.015 & 1.20 \\
\hline INF & 8.03 & 13.59 & 44.61 & 0.061 & $2.612 * *$ & 0.017 & 1.36 & 0.040 & 1.79 & -0.128 & 1.44 & 0.059 & $2.59 * *$ & 0.002 & 0.15 \\
\hline EXR & 1.08 & 2.14 & 11.88 & 0.055 & $2.289 * *$ & 0.022 & 1.69 & 0.017 & 0.74 & 0.026 & 1.72 & 0.065 & 2.33 & 0.021 & 1.71 \\
\hline \multicolumn{16}{|c|}{ Mean Predicted } \\
\hline $\mathrm{p}$-value & 0.55 & 0.53 & & 0.50 & & 0.50 & & 0.51 & & 0.51 & & 0.50 & & 0.52 & \\
\hline Obs. & 93 & 509 & & 91 & & 91 & & 91 & & 91 & & 91 & & 91 & \\
\hline
\end{tabular}

$*, * *, * * *$ indicate statistical significance at $10 \%, 5 \%$ and $1 \%$ test levels, respectively (Boots trap with 1000 repetitions)

Note: Equations include constant and lagged variables of the control variables. 
Table 7. Average Treatment Effect for Decreased Macroprudential Measures

DECREASED (EXPANSIONARY POLICY) MEASURES ON CAPITALFLOWS: MEANS FOR TREATED AND CONTROL GROUPS USING DIFFERENT MATCHING ALGORITHMS

\begin{tabular}{|c|c|c|c|c|c|c|c|c|c|c|c|c|c|c|c|}
\hline & \multirow{4}{*}{$\begin{array}{l}\text { Mean: } \\
\text { Treated } \\
\text { Group } \\
\left(\mu_{\mathrm{t}}\right)\end{array}$} & \multirow{3}{*}{\multicolumn{2}{|c|}{$\begin{array}{l}\text { Mean: } \\
\text { Unmatched Stand. }\end{array}$}} & \multicolumn{4}{|c|}{ NEAREST NEIGHBOUR } & \multicolumn{5}{|c|}{ 5-NEAREST NEIGHBOURS } & \multicolumn{3}{|c|}{ GAUSSIAN KERNEL } \\
\hline & & & & & & & \multirow{2}{*}{\multicolumn{2}{|c|}{ Mean(KAO): }} & \multirow{2}{*}{\multicolumn{2}{|c|}{ Mean(KAI): }} & \multirow[b]{2}{*}{ Mean(KAO): } \\
\hline & & & & \multicolumn{2}{|c|}{ Mean(KAI): } & \multicolumn{2}{|c|}{$\operatorname{Mean}(\mathrm{KAO})$ : } & & \multicolumn{2}{|c|}{ Mean(KAI): } & & & & & \\
\hline & & $\begin{array}{l}\text { Control } \\
\left(\mu_{\mathrm{c}}\right)\end{array}$ & Diff. & $\begin{array}{l}\text { Matchec } \\
\text { Control }\end{array}$ & $t$-stat & $\begin{array}{l}\text { Matched } \\
\text { Control }\end{array}$ & d $t$-stat & & $\begin{array}{l}\text { Matched } \\
\text { Control }\end{array}$ & $t$-stat & Matched & d $t$-stat & \multicolumn{2}{|c|}{$\begin{array}{l}\text { Matched } \\
\text { Control } t \text {-stat }\end{array}$} & $\begin{array}{l}\text { Matched } \\
\text { Control } t \text {-stat }\end{array}$ \\
\hline $\mathrm{i}$ & 6.76 & 4.62 & 74.46 & 0.041 & $3.44 * * *$ & -0.035 & -6.96 & $* *$ & 0.0409 & 0.59 & -0.034 & $-6.88 * * *$ & 0.039 & $3.49 * * *$ & $-0.034-6.40 * * *$ \\
\hline $\mathrm{i}-\mathrm{i}^{\text {us }}$ & 6.25 & 4.23 & 74.32 & 0.023 & -0.12 & -0.015 & -3.12 & $* *:$ & 0.0231 & $2.49 * *$ & 0.000 & -0.03 & 0.040 & $4.21 * * *$ & $-0.036 \quad 3.63 * * *$ \\
\hline VIX & -4.34 & 1.32 & -64.30 & 0.021 & 0.41 & -0.075 & -15.47 & $* *:$ & 0.0211 & $-2.11 * *$ & -0.040 & $-7.92 * * *$ & 0.020 & 1.87 & $-0.027-1.51$ \\
\hline LEV & 0.66 & 0.66 & -29.07 & 0.023 & 1.97 & -0.100 & -20.22 & $* *$ : & 0.0233 & $2.36 * * *$ & -0.034 & $-6.72 * * *$ & -0.009 & 1.62 & $-0.017 \quad-2.20$ \\
\hline G & 0.60 & 3.09 & -56.44 & -0.030 & $-2.59 * * *$ & -0.296 & -49.68 & $* *$ & -0.03 & 0.63 & -0.019 & $-3.79 * * *$ & -0.003 & -0.33 & $-0.104-6.43 * * *$ \\
\hline INF & 9.61 & 13.06 & 54.63 & 0.003 & 0.27 & -0.141 & -26.70 & $* *$ : & 0.0032 & -1.12 & -0.185 & $-35.94 * * *$ & -0.006 & -0.53 & $-0.157-6.92 * * *$ \\
\hline EXR & 4.92 & 1.67 & 44.11 & 0.013 & 1.25 & -0.026 & -5.39 & $* *$ : & 0.0126 & $-6.68 * * *$ & -0.167 & $-31.54 * * *$ & -0.043 & $-4.97 * * *$ & $-0.106-17.0 * * *$ \\
\hline \multicolumn{16}{|c|}{ Mean Predicted } \\
\hline p-value & 0.54 & 0.52 & & 0.50 & & 0.52 & & & 0.51 & & 0.51 & & 0.50 & & 0.51 \\
\hline Obs. & 59 & 541 & & 59 & & 59 & & & 59 & & 59 & & 59 & & 59 \\
\hline
\end{tabular}

$*, * *, * * *$ indicate statistical significance at $10 \%, 5 \%$ and $1 \%$ test levels, respectively (Bootstrap with 1000 repetitions) Note: Equations include constant and lagged variables of the control variables.

The results of PSM technique, as discussed above, were used in expressing causal assumptions to be cognitively meaningful. The observed macroeconomic variables used in this study were used in expressing a causal inference. Overall, the results show that the effect of increased measures for macroprudential policy are more meaningful on capital outflow than on capital inflow and, to a lesser extent, the effects of decreased measure for macroprudential policy is more meaningful on capital inflow.

\section{Concluding Remarks}

The recent financial crisis will continue to attract many researchers endeavouring to understand the nature of crises and their resulting consequences in global financial markets. The dynamics of any economic crisis may be grouped into several main areas, such as the causes of disruptions in the market, the aftermath and policy interventions for the prevention of distortions in the economic environment. The last dynamic deserves further attention, as history repeats itself and, to date, policy makers have failed to prevent economic crises. The behaviour of central banks, as well as the process of using policy instruments to realise central banking objectives have also evolved over time. The conventional approach to central banking with the objective of price stability through monetary policy instruments, especially during times of zero-lower-bound interest rates, have failed to create macroeconomic stability. The results presented in this study show that central banks in emerging markets have diversified 
their strategies to include unconventional methods together with frequent use of macroprudential policy instruments. Soundness of the financial markets implicitly, together with price stability, are on the list of emerging market central banks' macroeconomic objectives. This study shows evidence that both monetary and macroprudential policy instruments contribute to the stability of financial markets; however, it also shows a weak evidence that macroprudential policy instruments support price stability. Thus, the use of unconventional methods should be defined explicitly for effective central banking in pursuing internal and external objectives.

Another conclusion of this study is regarding the exploration of the behaviour of foreign investors in emerging economies. If foreign investors continue to only heed short term variables such as asset price volatility and target interest rates and disregard long term variables such as domestic business cycle, credit growth rate and financial sector borrowing, the vulnerability of emerging markets will increase and policy makers will need to be on their toes in order to keep their economies from collapsing. Macroprudential policy instruments aiming to control capital flow volatility eventually, focus on foreign investors to prevent sudden stops. However, this study showed that it is domestic investors, rather than foreign, that respond to macroprudential policy changes.

\section{Appendices}

\subsection{Data}

There are 25 countries included in this analysis. These are Albania, Brazil, Bulgaria, Chile, China, Czech Republic, Hong Kong, Hungary, India, Indonesia, Kazakhstan, Korea, Latvia, Lithuania, Malaysia, Mexico, Peru, Philippines, Poland, Romania, Russia, Singapore, Thailand, Turkey and Uruguay. The data range covers 2008Q1-2013Q4. All data have been obtained from International Monetary Fund (IMF) International Financial Statistics (IFS), national central banks and national statistical departments. Details for the sources of data are listed below.

CAPITAL INFLOW (KAI) AND OUTFLOW (KAO): Portfolio investment inflow and outflow are used and data was obtained from the IMF. 
GDP: Data for Argentina and Mexico was obtained from OECD; for all other countries, data was obtained from the IMF.

INTEREST RATE (i): 3-month interbank rate for Poland, Romania Czech Republic, Hungary, Latvia and Lithuania, obtained from Eurostat. Bolivia, India, China, Hong Kong obtained from central banks. Others are monetary policy related interest rates from IMF.

VIX: Chicago Board Options Exchange (CBOE) Rate Market Volatility Index obtained from Bloomberg and CBOE.

LEVERAGE GROWTH (LEV): Banking leverage is calculated by claims on private sector divided by the sum of transferable deposits included in broad money and other deposits included in broad money. Data obtained from IMF. However, IMF data is not available for Czech Republic, Hong Kong, Hungary, India, Latvia, Lithuania and Singapore. Therefore, domestic economy leverage (domestic credits divided by GDP) was used and data was obtained from central banks and national statistical departments.

DOMESTIC CREDIT GROWTH (CR): Domestic credits include the sum of net claims on central government, claims on other financial corporations, claims on public non-financial corporations and claims on private sector (for Bulgaria, only net claims on central government is used due to availability). Data for Bulgaria, Hong Kong, India, Latvia, Lithuania, Peru, Poland and Singapore obtained from national statistical departments, others from the IMF.

LOAN-TO-VALUE (LTV) AND RESERVE REQUIREMENTS (RR): Dummy variables are used when there are policy changes, obtained from national central banks and other sources (Lim et al. 2011 and Shim et al. 2013).

EXCHANGE RATES (EXR): Nominal exchange rates, national currency per US dollars, obtained from IMF International Financial Statistics.

\section{References}

Ahmed S, Zlate A (2013) Capital Flows to Emerging Market Economies: A brave new world? Board of Governors of the Federal Reserve System International Finance Discussion Papers 1081, June 2013.

Akinci O, Olmsted-Rumsey R (2015) How effective are macroprudential policies? An empirical investigation. International Finance Discussion Papers 1136. 
Angelini P, Neri S, Panetta F (2012) Monetary and Macroprudential Policies. European Central Bank Working Paper Series No. 1449, July 2012.

Arellano M, Bond S (1991) Some Tests of Specification for Panel Data: Monte Carlo Evidence and an Application to Employment Equations. The Review of Economic Studies, 58, pp 277-297.

Augouleas E (2015) Bank Leverage Ratios and Financial Stability: A Micro- and Macroprudential Perspective. Levy Economics Institute of Bard College Working Paper No. 849, October 2015.

Bank of International Settlements (1986) Recent Innovations international banking. Report prepared by a study group established by the central banks if the Group of Ten countries, Basel, April (Cross Report)

Blunden G (1987) Supervision and Central Banking. Bank of England Quarterly Bulletin, August.

Bogdanov B (2014) Liberalised Capital Accounts and Volatility of Capital Flows and Foreign Exchange Rates. European Economy Economic Papers 521, July.

Bose N (2002) Inflation, the Credit Market and Economic Growth. Oxford Economic Papers 54(3), pp 412-434.

Bruno V, Shim I, Shin HS (2015) Comparative assessment of macroprudential policies, BIS Working Paper No 502, June 2015.

Caliendo M, Kopeinig S (2005) Some practical guidance for the implementation of propensity score matching. IZA Discussion Paper Series, IZA DP No. 1588, May.

Cline W (2010) Financial globalisation, economic growth, and the crisis of 2007-2009. Peterson Institute of International Economics: Washington, DC.

Crockett AD (2000) Marrying the micro- and macro-prudential dimensions of financial stability. BIS Management Speeches before the Eleventh International Conference of Banking Supervisors, Basel, 20-21 September 2000.

Dehejia RH, Wahba S (2002) "Propensity Score Matching Methods for Non-experimental Causal Studies.” Review of Economics and Statistics 84(1): 151-161. 
Fernández-Arias E, Montiel PJ (1996) The surge in capital inflows to developing countries: An analytical Overview. The World Bank Review 10(1), pp 51-77.

Forbes KJ (2007) The microeconomic evidence on capital controls: No free lunch. In Sebastian Edwards, ed., Capital Controls and Capital Flows in Emerging Economies: Policies, Practices, and Consequences. Chicago: University of Chicago Press, pp 171-202.

Forbes KJ, Fratzscher M, Straub R (2015) Capital flow management measures: What are they good for? Journal of International Economics 99, pp 76-97.

Forbes KJ, Warnock FE (2011) Capital flow waves: Surges, stops, flight, and retrenchment. NBER Working Paper Series, Working paper 17351, August.

Gagnon JE (2011) Flexible exchange rates for a stable world economy. Peter G. Peterson Institute for International Economies, Washington, DC.

Galati G, Moessner R (2011) Macroprudential Policy - a literature review. BIS Working Papers No 337, February 2011.

Galati G, Moessner R (2014) What do we know about the effects of macroprudential policy? DNB Working Paper No. 440, September 2014.

Ghosh AR, Quereshi MS, J.I. Kim, J. Zalduendo (2014) Surges. Journal of International Economics 92, pp 266-285.

Glick R, Hutchison M (2005) Capital Controls and Exchange Rate Instability in Developing Economies. Journal of International Money and Finance, April.

Gourinchas P-O, Jeanne O (2006) Capital Flows to Developing Countries: Allocation puzzle. Working paper 13602. National Bureau of Economic Research.

Hansen LP (1982) Large Sample Properties of Generalised Method of Movements Estimators. Econometrica 50, pp 1029-1054.

Ho DE, Imai K, King G, Stuart EA (2007) Matching as nonparametric pre-processing for reducing model dependence in parametric causal inference. Political Analysis 15, pp 199236.

IMF (2012) The liberalisation and management of capital flows: An institutional view, November 14. 
IMF (2013a) The interaction of Monetary and Macroprudential Policies. International Monetary Fund, January 29.

IMF (2013b) Unconventional Monetary Policies- Recent Experience and Prospects. International Monetary Fund, April 18.

Institute of International Finance (IIF) ( 2015) Capital Markets Monitor: Key issues, June 2015.

Kawata H, Kurachi Y, Nakamura K, Teranisi Y (2013) Impact of macroprudential policy measures on economic dynamics. Bank of Japan Working Paper Series No. 13-E-3, February 2013.

Klein M (2012) Capital controls: Gates versus walls. Brookings Papers on Economic Activity, Fall, pp 317-355.

Lechner M (2002) Some practical issues in the evaluation of heterogenous labour market programmes by matching methods. Journal of Royal Statistical Society, 165, pp 59-82

Lim C, Columba F, Costa A, Kongsamut P, Otani A, Saiyid M, Wezel T, Wu X (2011) Macroprutential Policy: What instruments and how to use them? Lessens from country experiences. IMF Working Paper W/11/238. International Monetary Fund.

Miranda-Agrippino S, Rey H (2012) World Asset Markets and Global Liquidity. Presented at the Frankfurt ECB BIS Conference, February 2012, mimeo, London Business School.

Morgan SL, Windship C (2015) Counterfactuals and causal inference: methods and principles for social research. $2^{\text {nd }}$ edition, Cambridge University Press.

Nier E, Sedik TS, Mondino T (2014) Gross Private Capital Flows to Emerging Markets: Can the Global Financial Cycle be Tamed? IMF Working Paper WP/14/196.

Ostry JD, Ghosh AR, Chamon M, Qureshi MS (2012) Tools for managing financial stability risks from capital inflows. Journal of International Economics 88(2), pp 407-421.

Pearl J (2010) The foundations of causal inference. Social Methodology 40, pp 75-149.

Powell H J (2013) Advanced Economy Monetary Policy and Emerging Market Economies. Speech at the Federal Reserve Bank of San Francisco 20123 Asia Economic Policy Conference. 
Prasad ES, Rajan RG, Subramanian A (2007) Foreign Capital and Economic Growth. Brookings Papers on Economic Activity, 38, pp 153-230.

Rey H (2013) Dilemma not Trilemma: The global financial cycle and monetary policy independence. Mimeo Kansas FED Jackson Hole Conference, Wyoming, August 22-24.

Rodman D (2006) An Introduction to "Difference" and "System" GMM in Stata. Center for Global Development WP 103, December 2006.

Rosenbaum PR, Rubin DB (1983) The Central Role of the Propensity Score in Observational Studies for Causal Effects. Biometrika 70(1), pp 41-55.

Sargan, JD (1958) The Estimation of Economic Relationships Using Instrumental Variables. Econometrica 26, pp 393-415.

Shim I, Bogdanova B, Shek J, Subeluyte A (2013) Database for policy actions on housing markets. BIS Quarterly Review, BIS, September 2013.

Sianesi B (2001) Implementing propensity score matching with STATA. Presentation at the UK Stata Users Group, VII Meeting. London, May.

Taylor MP, Sarno L (1997) Capital flows to developing countries: Long- and short-term determinants. The World Bank Review 11(3), pp 451-470.

Unsal F (2011) Capital Flows and Financial Stability: Monetary policy and macroprudential responses. IMF Working Paper WP/11/189. 